\title{
Novel and Traditional Cardiovascular Risk Factors in Adolescents
}

\author{
Alice P.S. Kong1 and Kai Chow Choi ${ }^{2}$ \\ ${ }^{1}$ Department of Medicine and Therapeutics, Faculty of Medicine, \\ The Chinese University of Hong Kong, \\ 2The Nethersole School of Nursing, Faculty of Medicine, \\ The Chinese University of Hong Kong, \\ Hong Kong
}

\section{Introduction}

Cardiovascular diseases are prevalent conditions which impose significant negative impacts on the healthcare system. According to World Health Organization (WHO), noncommunicable diseases (NCD) including cardiovascular diseases account for more than $60 \%$ of all deaths globally. Overweight/obesity, diabetes, hypertension and dyslipidemia are all traditional cardiovascular risk factors in adults. Of particular concern, adolescence obesity and its associated cardiovascular risk and co-morbidities have substantial tracking into adulthood (1-4).

Advances in technology of agriculture have helped to increase food production resulting in easily available, excessive provision of food in many developed countries. Urbanization also leads to changes in leisure activities from doing sports to television viewing and computer games. As a consequence to increasing demand from school and leisure activities, sleep deprivation is another novel risk factor contributing to the escalation of cardiovascular risk in the youth populations. In addition, exposure to heavy metals is increasingly recognized as a consequence of urbanization and may contribute to premature atherosclerosis.

\section{Traditional cardiovascular risk factors in adolescents}

\subsection{Overweight and obesity}

Overweight/obesity is an important and well-known cardiovascular risk factor in children, adolescents and adults. Obesity is closely associated with clustering of cardiovascular risk factors with insulin resistance being the possible link(5). Obesity is also associated with increased risk of a number of co-morbidities and premature mortality in both adult and the youth populations (2, 6-11). In a British cohort followed up for 57 years, overweight in childhood was associated with 1.5 times increased risk of all-cause mortality and two-fold increased risk of ischemic heart disease (6). Co-morbidities of adolescence obesity include type 2 diabetes mellitus, micro-inflammation, atherogenic dyslipidemia, hypertension, left ventricular hypertrophy, premature atherosclerosis leading to cardiovascular diseases, 
obstructive sleep apnoea, gastroesophageal reflux disease, depression and other psychosocial abnormalities (2, 12-16). Clustering of traditional cardiovascular risk factors, namely metabolic syndrome, is noted to have ethnic disparities (17)and the prevalence also varies according to the different definitions of metabolic syndrome adopted $(11,18)$. Despite the controversies regarding the exact definitions of metabolic syndrome in both adults and children(19, 20), International Diabetes Federation (IDF) recently suggests abdominal obesity as the core criteria in making a diagnosis of metabolic syndrome(21), highlighting the pivotal role of obesity in linking these cardiometabolic abnormalities and cardiovascular diseases.

Childhood obesity can predict the cardiovascular risk in adulthood (22). With increasing childhood obesity, there is increasingly early onset of atherosclerosis(23). In a study involving Hong Kong Chinese overweight children aged 9-12 years (mean BMI $25 \pm 3$ $\mathrm{kg} / \mathrm{m}^{2}$ ), BMI was independently associated with impaired arterial endothelial function and increased carotid intimal medial thickness, which are early markers of atherosclerosis (24). An important message from this study is that these obesity-related early vascular dysfunctions are partially reversible by lifestyle modifications (25).

Prevalence of childhood and adolescence overweight/obesity has marked variation among developed and developing countries. The prevalence of childhood and adolescence obesity has tripled between 1980 and 2000 in United States (US) and doubled between 1985 and 1995 in Australia(26). In a systemic review of published literatures examining data of prevalence of overweight/obesity among children living in developing countries, lowest prevalence was found in India and Sri Lanka whereas highest prevalence was found in Eastern Europe and the Middle East(27).When comparing epidemiological and clinical studies examining childhood and adolescence overweight/obesity, the diagnostic criterion used to define overweight/obesity should be interpreted with cautions. Despite the importance to identify overweight/obese individuals and screen for associated cardiovascular risk factors early, there is no consensus regarding the diagnostic criteria of childhood and adolescence obesity (28). Compared to adults, assessment of overweight and obesity in children and adolescents are different and not that straightforward. We need to take growth and puberty into consideration because BMI is anticipated to change with age and depends on gender. Gender difference is particularly important in the assessment of childhood and adolescence obesity as girls and boys enter puberty at different pace. In children and adolescents, there are ongoing debates regarding the optimal cutoff values of BMI and waist circumference (WC) to define childhood and adolescence overweight and obesity with various diagnostic criteria adopted by different countries and authorities (28-32).

From published pediatric literatures, at least four diagnostic criteria have been used for the definition of overweight and obesity in children and adolescents $(11,28)$ :

1. An international BMI-for-age reference curve for defining overweight and obesity in children 2 to 18 years of age by the US National Center for Health Statistics, Centers for Disease Control and Prevention (CDC) and the International Obesity Task Force (IOTF) in 2000 (IOTF criteria) (31).

These criteria were based on median BMI by age and gender in six nationally representative datasets from Brazil, Hong Kong, Netherlands, Singapore, United Kingdom (UK) and the US from an international growth survey in 2000. These surveys had over 10,000 subjects 
each and altogether covered 97,876 boys and 94,841 girls. Overweight and obesity were defined as BMI-for-age $\geq 25$ and $\geq 30 \mathrm{~kg} / \mathrm{m}^{2}$ respectively.

2. A national BMI reference curve for Chinese children and adolescents reported by the Group of China Obesity Task Force (COTF) in 2004 (COTF criteria) (33).

These criteria were based on the Chinese National Survey on Students Constitution and Health in 2000 involving 244,200 primary and secondary Chinese students aged 7-18 years. Overweight and obesity were defined as BMI-for-age $\geq 24$ and $\geq 28 \mathrm{~kg} / \mathrm{m}^{2}$ respectively.

3. CDC 2000 Growth Charts for the US (CDC criteria) (34).

These criteria were based on the US National data collected in a series of 5 surveys between 1963 and 1994 for children and adolescents aged 2-20 years. Overweight and obesity were defined as BMI-for-age $\geq 85^{\text {th }}$ and $\geq 95^{\text {th }}$ percentiles respectively.

4. The Hong Kong Growth Survey (HKGS) conducted in 1993 with sex-specific reference charts of weight-for-height (HKGS criteria) (35).

This was a territory-wide cross-sectional growth survey which covered around 25,000 Hong Kong Chinese children from birth to 18 years of age. Childhood obesity in this survey was defined as weight $>$ median weight for height $\times 120 \%$. No definition for childhood overweight was set in this survey.

In recent years, increasing clinical attention has been drawn to central obesity because central body fat is a better predictor than overall body fat for cardiovascular risk factors in both adults $(36,37)$ and children $(7,38,39)$. Central obesity reflects excess visceral adiposity which is a major culprit for insulin resistance and associated cardiovascular disease in both adults and children $(7,38,40-43)$. WC and WC-derived indexes such as waist-to-hip ratio (WHR) and waist-to-height ratio (WHTR) are commonly employed anthropometric measurements as proxy measures of central obesity. In Caucasian adults, WC $\geq 102 \mathrm{~cm}$ in men and $\geq 88 \mathrm{~cm}$ in women are used to define central obesity $(1,3)$. The corresponding cutoff values in Chinese and South Asian men and women are $\geq 90 \mathrm{~cm}$ and $\geq 80 \mathrm{~cm}$ respectively $(5$, 44). In adults, there are at least 14 different methods to quantify WC (19). In pediatric literatures, measurements of WC have been described at 5 different sites: 1) midway between the lowest rib and superior iliac crest $(45-49) ; 2)$ at the umbilical level $(50,51)$; 3$)$ at the narrowest point of the torso (52); 4) at the level of the right upper iliac crest (53); and 5) at the level of $2 \mathrm{~cm}$ above the umbilicus (54). Based on the 2005/2006 Hong Kong Growth Survey including 14,842 Hong Kong Chinese school children aged 6 to 18 years, reference values and percentile curves for WC and WHRT are established (49). These charts are based on WC measured midway between the lowest rib and superior iliac crest and provide reference values for estimation of central obesity in local Hong Kong Chinese youth populations.

In summary, adolescence obesity is a global concern because obesity associated cardiovascular risk factors and abnormalities are potentially reversible in early disease stage. Despite the epidemic of childhood and adolescence obesity worldwide, the most appropriate criterion to ascertain the diagnosis is still inconclusive. Given the high rates of adolescence obesity, adolescents are important population for monitoring and intervention. 


\subsection{Diabetes}

Diabetes is a disorder of glucose metabolism with complex interplays between genetic, lifestyle and environmental factors. Historically, type 2 diabetes is much less common in children and adolescents compared to autoimmune type 1 diabetes and type 2 diabetes has once been thought to be non-existent in children (55). However, with increasing prevalence of obesity worldwide, type 2 diabetes in children and adolescents is increasing at an alarming pace (55). Atherosclerosis starts in young people with type 2 diabetes(56). The general awareness of type 2 diabetes in adolescents should be escalated, particularly in those with obesity and family history of type 2 diabetes. American Diabetes Association (ADA) (57)has recommended the testing for type 2 diabetes in asymptomatic children and adolescents who are: aged 10 years or at onset of puberty, overweight (BMI $>85^{\text {th }}$ percentile for age and sex, weight for height $>85^{\text {th }}$ percentile, or weight $>120 \%$ of ideal for height), plus any two of the following risk factors:

1. family history of type 2 diabetes in first- or second-degree relative;

2. race/ethnicity (Native American, African American, Latino, Asian American, Pacific Islander);

3. clinical evidence and/or association of insulin resistance, e.g. polycystic ovarian syndrome, metabolic syndrome, acanthosis nigricans, etc;

4. maternal history of gestational diabetes during the child's gestation.

ADA recommends a three yearly screening in these at-risk young individuals (57). In making the diagnosis of diabetes in adolescents, the possibility of "hybrid" disease with obesity and concomitant diseases with compromised insulin secretion such as maturityonset diabetes of the young (MODY) or latent autoimmune diabetes in adult (LADA) should always be considered(58).

For adolescents with type 1 diabetes who present with acute decompensation and diabetic ketoacidosis (DKA), insulin therapy is the standard therapy. Insulin use is also advised in youth with type 2 diabetes who present with severe hyperglycemia $(\geq 11.1 \mathrm{mmol} / \mathrm{L})$, $\mathrm{HbA}_{1 \mathrm{c}}>8.5 \%$ or severe manifestation of insulin deficiency such as DKA (59). Although oral antidiabetic agents are not recommended in treatment of type 1 diabetes traditionally, metformin use in conjunction with insulin in adolescents with poorly controlled diabetes has been reported to improve their glycemic control (60). Despite the escalating rate of type 2 diabetes in the youth, therapeutic modalities remain limited with metformin being the only U.S. Food and Drug Administration (FDA)-approved oral treatment for youth with type 2 diabetes (61). Similar recommendation has been adopted in other countries (62).

\subsection{Hypertension}

The global epidemic of obesity is leading to a shift in the diabetes, as well as hypertension distribution towards increasing levels in children and adolescent $(63,64)$. In addition, physical inactivity and high salt/sodium intake contribute to the rise in the prevalence of hypertension in the youth. Similar to childhood and adolescence obesity, there is also tracking of high blood pressure from childhood into adulthood(65, 66). Autopsy findings from Bogalusa Heart Study and the Pathobiologic Determinates of Atherosclerosis in Youth (PDAY) have shown that higher blood pressure in the youth populations is associated with increased atherosclerosis $(67,68)$. 
Accurate measurement of blood pressure and correct diagnosis of hypertension or prehypertension in the youth populations are important to prevent end-organ damage in adults. The fourth report on the diagnosis, evaluation and treatment of high blood pressure in children and adolescents has suggested a diagnosis of hypertension as $>95^{\text {th }}$ percentile for gender, age and height on $\geq 3$ occasions. Stage 1 hypertension is diagnosed if systolic or diastolic blood pressure reaches $9^{\text {th }}$ to $99^{\text {th }}$ percentile plus $5 \mathrm{mmHg}$ on at least 3 separate occasions(69) whereas stage 2 hypertension is defined as $>99^{\text {th }}$ percentile plus $5 \mathrm{mmHg}$. Various diagnostic cutoff values have been suggested for defining hypertension and prehypertension in the youth population (Table 1). Pre-hypertension is defined as $>120 / 80$ $\mathrm{mmHg}$ or $\geq 90^{\text {th }}$ to $<95^{\text {th }}$ percentile $(69)$. Blood pressure increases with age, yet there is limited information regarding the time course for children and adolescents with prehypertension to progress to hypertension. For early diagnosis of pre-hypertension and hypertension, reference blood pressure standards by sex-, age-, weight- and height are clinically important $(70,71)$.

\begin{tabular}{|l|l|l|l|l|}
\hline $\begin{array}{l}\text { The } 4^{\text {th }} \text { report on the } \\
\text { diagnosis, } \\
\text { evaluation, and } \\
\text { treatment of high } \\
\text { BP in children and } \\
\text { adolescents(69) }\end{array}$ & $\begin{array}{l}\text { Cool et al (76) , } \\
\mathbf{( 7 7 )} \text { and Kong et } \\
\text { al (39, 78) }\end{array}$ & $\begin{array}{l}\text { Cruz et al (79) } \\
\text { and de Ferranti } \\
\text { et al (75) }\end{array}$ & Weiss et al (80) & $\begin{array}{l}\text { Zimmet et al } \\
\mathbf{( 2 1 )}\end{array}$ \\
\hline $\begin{array}{l}\text { BP }>95^{\text {th }} \text { percentile } \\
\text { for gender, age and } \\
\text { height on } \geq 3 \\
\text { occasions }\end{array}$ & $\begin{array}{l}\mathrm{BP} \geq 90^{\text {th }} \\
\text { percentile for } \\
\text { gender, age and } \\
\text { height }\end{array}$ & $\begin{array}{l}\mathrm{BP}>90^{\text {th }} \\
\text { percentile for } \\
\text { gender, age and } \\
\text { height }\end{array}$ & $\begin{array}{l}\text { BP }>95^{\text {th }} \\
\text { percentile for } \\
\text { gender, age and } \\
\text { height }\end{array}$ & $\begin{array}{l}\mathrm{BP} \geq 130 / 85 \\
\mathrm{mmHg}\end{array}$ \\
\hline
\end{tabular}

Table 1. Diagnostic criteria used in pediatric literatures for definition of hypertension. Blood pressure: BP.

White coat hypertension is a well recognized phenomenon of transiently high blood pressure related to stress. Home-clinic blood pressure difference can vary substantially by age in children with the difference reduced with advancing age and substantially diminshed after 12 year-old(72). Therefore, ambulatory blood pressure (AMBP) is gaining popularity in both children and adults due to the stronger correlation between high AMBP with target organs damage observed in an emerging number of studies in both adults and paediatric populations (73).

For youth with pre-hypertension and hypertension, a search and thorough evaluation for secondary causes is recommended as secondary hypertension is more common in children than adults(69). If secondary hypertension is ruled out, children and adolescents with prehypertension should start lifestyle modifications(69). For stage 2 hypertension, drug therapy should be initiated but for those with stage 1 hypertension, pharmacological treatment is recommended if symptomatic, evidence of end-organ damage, concomitant diabetes or persistent high blood pressure despite non-pharmacological measures(69). A detailed elaboration of the dosage, dosing interval and precautions of different types of antihypertensive drugs for children with hypertension has been described in the fourth report on the diagnosis, evaluation and treatment of high blood pressure in children and adolescents(69). 


\subsection{Dyslipidemia}

Dyslipidemia continue to track from childhood into adulthood(74). Similar to the controversies in diagnosis of obesity and hypertension, there is no consensus regarding the definition of dyslipidemia in children and adolescents. Typical dyslipidemia in children and adults with obesity and insulin resistance include increased triglyceride and decreased highdensity lipoprotein (HDL) cholesterol levels. The definitions of high triglyceride level in the youth range from $\geq 1.1 \mathrm{mmol} / 1$ (ie $\geq 100 \mathrm{mg} / \mathrm{dL}$ ) $(75), \geq 1.2 \mathrm{mmol} / 1(39,76,77)$ to $\geq 1.7$ $\mathrm{mmol} / 1(21,39,78)$. Some researchers adopt age-, sex- and/or race-specific percentile cutoff to diagnose hypertriglyceridemia with triglyceride $\geq 90^{\text {th }}$ percentile (79)and $>95^{\text {th }}$ percentile (80) used. For defining low HDL cholesterol levels in the pediatric literatures, a cutoff value of $\leq 1.03 \mathrm{mmol} / 1$ (ie $<40 \mathrm{mg} / \mathrm{dL})$ for all ages/sexes $(39,76-78),<1.03 \mathrm{mmol} / 1(21),<1.3$ $\mathrm{mmol} / 1$ (ie $<50 \mathrm{mg} / \mathrm{dL}$ )(75), or gender-specific cutoff $\leq 1.03 \mathrm{mmol} / 1$ for boys and $\leq 1.3$ $\mathrm{mmol} / \mathrm{l}$ for girls $(81)$, or percentile specific cutoff $<5^{\text {th }}$ percentile (age-, sex- and racespecific) $(80)$ and $\leq 10^{\text {th }}$ percentile (age-, sex- and height-specific) $(79,82)$ have been reported.

Low density lipoprotein (LDL) cholesterol remains to be the primary target of lipid control to prevent cardiovascular events in adults (83). Hence, majority of randomized controlled trials carried out in pediatric populations have also focused on the use of statins in youth with elevated LDL cholesterol levels. There is general consensus that statin should be initiated, in combination with diet and lifestyle modification if LDL cholesterol level > 4.1 $\mathrm{mmol} / 1$ (ie $160 \mathrm{mg} / \mathrm{dl}$ ) in at-risk youth $(84,85)$. Fibrates and niacin are lipid lowering drugs targeted to treat high triglyceride and low HDL cholesterol in adults, but neither drugs is approved for use by US FDA in the pediatric population.

\section{Novel cardiovascular risk factors in adolescents}

\subsection{Sleep}

Physiologically, average sleep duration decreases with progression from infancy, childhood to adolescence (86). With increasing demand from school and work, as well as changes in leisure activities such as television watching and computer games, the average sleep duration in the US adults has decreased from 9 hours per night a century ago to 6.9 hours per night in 2005 (87). In Sweden, the average sleep time has decreased from 9 hours per night in 1910 to 7.5 hours in 1990's in adults aged 20-64 years (88).

Sleep deprivation is now increasingly recognized as a lifestyle factor contributing to the global epidemic of childhood obesity and a novel, potentially reversible cardiovascular risk factor. Both laboratory and epidemiological studies suggested associations of obesity, insulin resistance, diabetes and cardiovascular disease with sleep debt in children, adolescents and adults (89-91). Increasing number of epidemiological studies show close association between sleep duration and obesity, which is evident as early as during early childhood (92-96). Short duration of sleep at age of 3 years predict future risk of obesity in childhood (92). In a Japanese study of 8274 children aged 6-7 years, an inverse relationship between hours of sleep and risk of childhood obesity was observed (93). Cross-sectional studies from US, Canada, UK, France, Germany and Japan suggest increased risk for overweight or obesity in Caucasian, Hispanic, African-American and Japanese children who sleep long hours than those with short sleep duration (93, 97-101). Prospective studies also suggest a predictive role of short sleep duration for overweight and obesity in Caucasians 
children $(92,102)$. Similar data from Chinese children and adolescents are comparatively sparse. A recent survey in Taiwan involving 656 boys and girls aged 13-18 years showed that sleep deprivation (defined as sleep $<6$ hours on schooldays) was associated with poor health status as measured by health-related behaviors in self-reported questionnaires (103).

Although the exact underlying mechanism linking sleep and obesity is not fully understood, preliminary results suggest a possible neurohormonal basis. There is evidence showing that sleep curtailment can activate the hypothalamo-pituitary-adrenal (HPA) axis (104). Van Cauter et al have demonstrated a significant rise in plasma cortisol levels in the following evening amongst subjects after partial (0400-0800 hours) and total sleep deprivation (37\% and $45 \%$ increases, $\mathrm{p}=0.03$ and 0.003 respectively) compared to those with normal sleep duration (2300-0700 hours) (104). In another study by Van Cauter et al, sleep debt was associated with adverse effects on carbohydrate metabolism and endocrine function (105). Glucose tolerance and thyrotropin concentrations were reduced while evening cortisol concentrations and activity of sympathetic nervous system were increased in the sleep debt group (4 hours per night) (105). Interestingly, these hormonal and metabolic changes are very similar to that accompanying normal ageing. Based on rodent studies, positive relation between sleep curtailment and hyperphagia has been noted. Van Cauter et al further demonstrated an inverse relationship between sleep debt and leptin, an important anorexigenic hormone secreted by adipocytes mediating the signals between adipose tissues and the hypothalamic regulatory centers $(106,107)$. In concert with this phenomenon, elevated ghrelin levels, the orexigenic hormone, were observed with reduced sleep duration accompanied by increased hunger and appetite (106). Similar results have also been reported by other workers showing associations between high BMI, short sleep duration, decreased leptin and elevated ghrelin levels (95). In addition, lipid and energy metabolism are regulated by circadian rhythm (108). Sleep problems may result in dysregulation of lipid metabolism and metabolic syndrome. In a national study in Japan, sleep duration in adults was closely related with serum lipid and lipoprotein levels (109). Recently, an association between atherogenic dyslipidemia and reduced sleep duration is reported in both U.S. and Hong Kong Chinese adolescents(110, 111).

\subsection{Inflammation}

Atherosclerosis can be regarded as a state of chronic, low-grade inflammation of the arterial wall, resulting from the interactions between plasma lipoproteins, peripheral blood mononuclear cells (PBMC) and the endothelium (112). It has been increasing recognized the clinical utility and prognostic role of serum inflammatory markers levels, in addition to traditional cardiovascular risk factors, in estimating cardiovascular risk in both adults and the youth populations. Both high circulating white cell counts and high serum high sensitivity C-reactive protein (hsCRP) are associated with increased risk of diabetes and associated complications in adults $(113,114)$. Increasing clinical evidence also suggest a link between inflammation, insulin resistance and cardiovascular risk factors in children and adolescents $(13,115-117)$. In a school children study including over 2,000 Hong Kong Chinese adolescents (median age: 16 years), overweight/obesity was associated with two to six-fold increased risk of having high hsCRP tertiles(13). In another cross-sectional study including 326 obese children aged 6-12 years (mean age 8.9 years), white blood cell counts were associated with plasma lipid profile (triglyceride, total and LDL cholesterol) and obesity indices (body mass index and WC)(117). 


\subsection{Heavy metals and environmental pollutants}

Apart from changes in habits and lifestyle, exposure to heavy metals is increasingly recognized as a consequence of urbanization. Most heavy metals cannot be metabolized by our body, and excessive accumulation in the body will disturb the normal functions of cells. Kidney is the key organ to eliminate heavy metals from the body. Heavy metals might lead to albuminuria through inducing oxidative stress to renal tubular cells $(118,119)$. Certain heavy metals have additive effect in inducing nephrotoxicity. For example, synergistic effect of arsenic (As) and cadmium (Cd) in causing renal damage has been demonstrated in Chinese general population(120). In addition, chronic exposure to toxic heavy metals may promote atherosclerosis and contribute to the development of chronic kidney disease and cardiovascular diseases $(119,121)$. Furthermore, air pollutants can provoke systemic proinflammatory and pro-thrombotic response and lead to increase in platelet counts and platelet activation(122). The significance of platelet activation and whether anti-platelet therapies can help reducing cardiovascular risk profiles in the youth populations is still a debatable subject(123). Further studies are required to examine the impact of heavy metals and environmental pollutants, as novel cardiovascular risk factors, in accelerating the development of cardiovascular disease in both adults and the youth populations(124).

\section{Controversies and the unmet needs to be addressed}

Lifestyle modification including regular exercise and diet are cornerstones of management of traditional cardiovascular risk factors including obesity, diabetes, dyslipidemia and hypertension. With recent evidence demonstrating the importance of adequate sleep duration in adolescents, education for a healthy sleep habit becomes one of the essential targets of lifestyle modification to prevent cardiovascular risk factors in the youth. Childhood and adolescence are vulnerable periods for habit formation due to substantial tracking of lifestyle habits and cardiovascular risk from this period into adulthood (125, 126). Thus, promoting healthy eating habit, regular exercise and healthy sleep habit in the youth are important strategies to curb the public health problem of obesity.

The optimal dietary approach to combat obesity and reduce cardiovascular risk factors is still a matter of controversies. Indeed, modern food-processing technology produces many food products with high glycemic index (GI). There is now emerging evidence showing that both the quality and quantity of dietary components can impact upon various physiological processes underlying energy metabolism and control of satiety which can provide the basis for dietary intervention in diabetes and obesity $(127,128)$. Epidemiological studies from US and China indicate that the risks of chronic diseases such as type 2 diabetes and coronary heart disease are strongly related to dietary GI $(129,130)$. High GI food, especially rice, the main carbohydrate-contributing food in Chinese, may increase risk of diabetes (130). WHO and Food and Agriculture Organization (FAO) recommend low-GI diet to prevent common chronic diseases of affluence, including obesity and type 2 diabetes (131). Recently, it has been suggested that low GI diet may have a role in the management of childhood obesity(132).

Promotion of regular exercise is another important aspect of lifestyle modifications in reducing cardiovascular risk in adolescents. Physical inactivity has been reported to be associated with obesity and other cardiovascular risk factors in adolescents(133). The role of exercise in weight management and control of cardiovascular risk factors is usually 
associated with its direct impact on energy expenditure and its potential to alter various components of appetite control and eating behavior. Low physical activity level predicts weight gain in different ethnic groups $(134,135)$. Regular physical activity maintains good health and prevents myocardial infarction, cardiovascular events and premature mortality (136, 137). Since early 1990s, many studies have demonstrated the beneficial effects of physical activity on promoting weight reduction and fat loss as well as reducing risk of diabetes and hypertension (138-141). Beneficial effects of exercise and diet are possibly beyond weight reduction. In a small scale study of obese Hong Kong Chinese children, combined intervention with diet and exercise reduced adiposity as well as improved lipid profiles and endothelial function compared to diet alone (25). In another study, a 6-week intervention with diet and strength training improved lipid profile in obese Chinese children (142).

WHO recommends regular and accumulated physical activities to prevent premature death and other adverse health outcomes (143). However, there are ongoing debates on the optimal frequency, duration and intensity of physical activity. Most international guidelines recommend moderate activity in adults, especially those who are older and less active (136). In a systematic review of over 850 published literatures, the authors recommended $\geq 60$ minutes physical activity of moderate to vigorous level in school-age youth (144). In 1988, the American College of Sports Medicine first recommended children and adolescents to have 20-30 minutes of vigorous exercise daily (145). In 2007, the Regional Office for Europe of the WHO made similar recommendations (146). Other guidelines suggested physical activity of moderate intensity at least twice or more weekly to enhance and maintain muscular strength, flexibility and bone health (20) while others suggested high levels and long duration of regular exercise (e.g. daily physical activity lasting at least 90 minutes) in the youth population (147).

As previously discussed, despite the escalating rate of diabetes and dyslipidemia in the youth population, therapeutic modalities remain limited with metformin and statin being the only US FDA approved oral treatment for youth with type 2 diabetes $(61,62)$ and dyslipidemia respectively $(84,85)$. More clinical researches are required to demonstrate the efficacy and safety for more therapeutic options in managing adolescents with type 2 diabetes and dyslipidemia.

\section{Conclusion}

In conclusion, cardiovascular disease is an increasing world health problem. In view of the substantial tracking of cardiovascular risk factors from adolescents to adulthood, there is an urgent need to intervene early with efficacious strategies to identify and treat the youth with cardiovascular risk factors. The traditional cardiovascular risk factors, namely overweight/obesity, diabetes, hypertension and dyslipidemia do not account for all cardiovascular deaths and novel factors, including lifestyle (e.g. sleep deprivation) and environmental (e.g. heavy metal poisoning), as well as the consequences and interactions related to these traditional and novel risk factors (e.g. inflammation and platelet activation) appear to be important, accounting for the dramatic recent changes in prevalence and would be of public health concern. Moreover, more intensive program for lifestyle modification and aggressive approach of pharmacological treatment should be considered in the youth at-risk of cardiovascular events. 


\section{Unmet Needs to be addressed in managing CVD risk factors in adolescents}

\section{Unmet Clinical Needs}

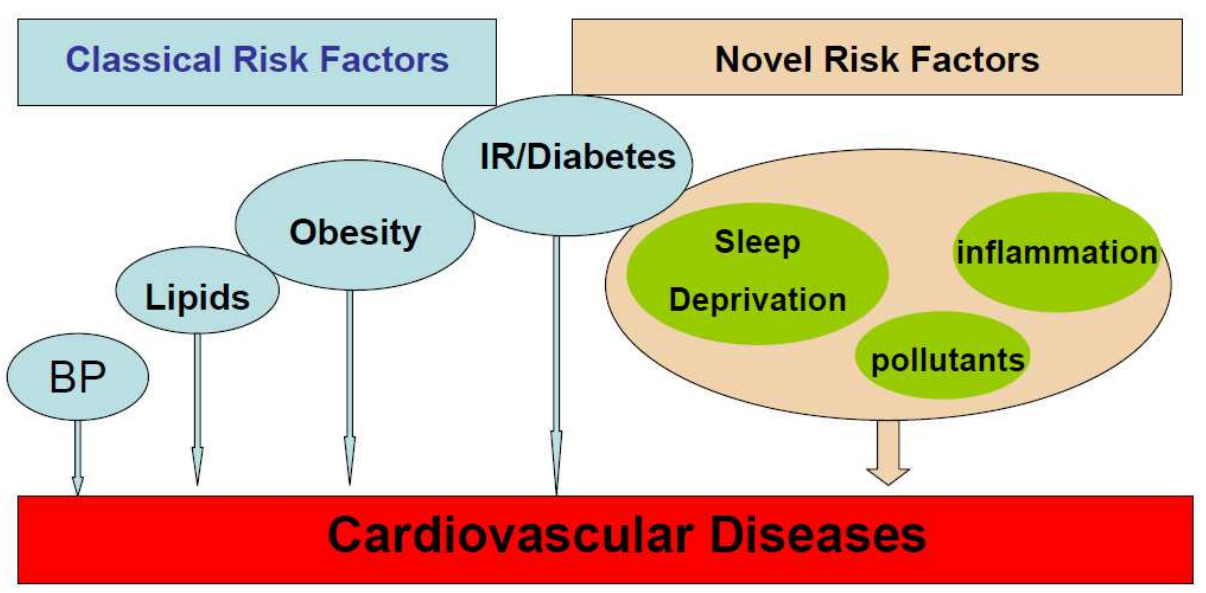

Fig. 1. Traditional and Novel Cardiovascular Risk Factors in Adolescents.

\section{Acknowledgement}

This book chapter and some of the cited studies were partially supported by funding from the Research Grants Council (RGC reference no.: CUHK 4055/01M, CUHK 4465/06M and CUHK 467410).

\section{References}

[1] Singh AS, Mulder C, Twisk JW, van Mechelen W, Chinapaw MJ. Tracking of childhood overweight into adulthood: a systematic review of the literature. Obes Rev 2008;9(5):474-88. Epub 2008 Mar 5.

[2] Daniels SR, Arnett DK, Eckel RH, Gidding SS, Hayman LL, Kumanyika S, et al. Overweight in children and adolescents: pathophysiology, consequences, prevention, and treatment. Circulation 2005;111(15):1999-2012.

[3] Srinivasan SR, Bao W, Wattigney WA, Berenson GS. Adolescent overweight is associated with adult overweight and related multiple cardiovascular risk factors: the Bogalusa Heart Study. Metabolism 1996;45(2):235-40.

[4] Guo SS, Huang C, Maynard LM, Demerath E, Towne B, Chumlea WC, et al. Body mass index during childhood, adolescence and young adulthood in relation to adult 
overweight and adiposity: the Fels Longitudinal Study. Int J Obes Relat Metab Disord 2000;24(12):1628-35.

[5] Kong AP, Chan NN, Chan JC. The Role of Adipocytokines and Neurohormonal Dysregulation in Metabolic Syndrome. Current Diabetes Reviews 2006;2:397-407.

[6] Gunnell DJ, Frankel SJ, Nanchahal K, Peters TJ, Davey Smith G. Childhood obesity and adult cardiovascular mortality: a 57-y follow-up study based on the Boyd Orr cohort. Am J Clin Nutr 1998;67(6):1111-8.

[7] Freedman DS, Dietz WH, Srinivasan SR, Berenson GS. The relation of overweight to cardiovascular risk factors among children and adolescents: the Bogalusa Heart Study. Pediatrics 1999;103(6 Pt 1):1175-82.

[8] Ebbeling CB, Pawlak DB, Ludwig DS. Childhood obesity: public-health crisis, common sense cure. Lancet 2002;360(9331):473-82.

[9] Patel DA, Srinivasan SR, Xu JH, Chen W, Berenson GS. Persistent elevation of liver function enzymes within the reference range is associated with increased cardiovascular risk in young adults: the Bogalusa Heart Study. Metabolism 2007;56(6):792-8.

[10] Romero-Corral A, Montori VM, Somers VK, Korinek J, Thomas RJ, Allison TG, et al. Association of bodyweight with total mortality and with cardiovascular events in coronary artery disease: a systematic review of cohort studies. Lancet 2006;368(9536):666-78.

[11] Kong AP, Chow CC. Medical consequences of childhood obesity: a Hong Kong perspective. Res Sports Med 2010;18(1):16-25.

[12] Berenson GS, Srinivasan SR, Bao W, Newman WP, 3rd, Tracy RE, Wattigney WA. Association between multiple cardiovascular risk factors and atherosclerosis in children and young adults. The Bogalusa Heart Study. $N$ Engl J Med 1998;338(23):1650-6.

[13] Kong AP, Choi KC, Ko GT, Wong GW, Ozaki R, So WY, et al. Associations of overweight with insulin resistance, beta-cell function and inflammatory markers in Chinese adolescents. Pediatr Diabetes 2008;9(5):488-95.

[14] Lauer RM, Lee J, Clarke WR. Factors affecting the relationship between childhood and adult cholesterol levels: the Muscatine Study. Pediatrics 1988;82(3):309-18.

[15] Lauer RM, Clarke WR. Childhood risk factors for high adult blood pressure: the Muscatine Study. Pediatrics 1989;84(4):633-41.

[16] Lumeng JC, Gannon K, Cabral HJ, Frank DA, Zuckerman B. Association between clinically meaningful behavior problems and overweight in children. Pediatrics 2003;112(5):1138-45.

[17] Schwandt P, Kelishadi R, Haas GM. Ethnic disparities of the metabolic syndrome in population-based samples of German and Iranian adolescents. Metab Syndr Relat Disord 2010;8(2):189-92.

[18] Kong AP, Ko GT, Ozaki R, Wong GW, Tong PC, Chan JC. Metabolic syndrome by the new IDF criteria in Hong Kong Chinese adolescents and its prediction by using body mass index. Acta Paediatr 2008;97(12):1738-42. Epub 2008 Oct 6.

[19] Reaven GM. The metabolic syndrome: requiescat in pace. Clin Chem 2005;51(6):931-8.

[20] Goodman E. Pediatric metabolic syndrome: smoke and mirrors or true magic? J Pediatr 2006;148(2):149-51. 
[21] Zimmet P, Alberti KG, Kaufman F, Tajima N, Silink M, Arslanian S, et al. The Metabolic Syndrome in Children and Adolescents - an IDF consensus report. Pediatr Diabetes 2007;8(5):299-306.

[22] Sun SS, Liang R, Huang TT, Daniels SR, Arslanian S, Liu K, et al. Childhood obesity predicts adult metabolic syndrome: the Fels Longitudinal Study. J Pediatr 2008;152(2):191-200.

[23] McGill HC, Jr., McMahan CA, Herderick EE, Malcom GT, Tracy RE, Strong JP. Origin of atherosclerosis in childhood and adolescence. Am J Clin Nutr 2000;72(5 Suppl):1307S-1315S.

[24] Woo KS, Chook P, Yu CW, Sung RY, Qiao M, Leung SS, et al. Overweight in children is associated with arterial endothelial dysfunction and intima-media thickening. Int J Obes Relat Metab Disord 2004;28(7):852-7.

[25] Woo KS, Chook P, Yu CW, Sung RY, Qiao M, Leung SS, et al. Effects of diet and exercise on obesity-related vascular dysfunction in children. Circulation 2004;109(16):1981-6.

[26] Ogden CL, Flegal KM, Carroll MD, Johnson CL. Prevalence and trends in overweight among US children and adolescents, 1999-2000. JAMA 2002;288(14):1728-32.

[27] Kelishadi R. Childhood overweight, obesity, and the metabolic syndrome in developing countries. Epidemiol Rev 2007;29:62-76.

[28] Ko GT, Ozaki R, Wong GW, Kong AP, So WY, Tong PC, et al. The problem of obesity among adolescents in Hong Kong: a comparison using various diagnostic criteria. BMC Pediatr 2008;8:10.

[29] Power C, Lake JK, Cole TJ. Measurement and long-term health risks of child and adolescent fatness. Int J Obes Relat Metab Disord 1997;21(7):507-26.

[30] Dietz WH, Robinson TN. Use of the body mass index (BMI) as a measure of overweight in children and adolescents. J Pediatr 1998;132(2):191-3.

[31] Cole TJ, Bellizzi MC, Flegal KM, Dietz WH. Establishing a standard definition for child overweight and obesity worldwide: international survey. BMJ 2000;320(7244):12403.

[32] Reilly JJ. Assessment of childhood obesity: national reference data or international approach? Obes Res 2002;10(8):838-40.

[33] Group of China Obesity Task Force. [Body mass index reference norm for screening overweight and obesity in Chinese children and adolescents]. Zhonghua Liu Xing Bing Xue Za Zhi 2004;25(2):97-102.

[34] Ogden CL, Kuczmarski RJ, Flegal KM, Mei Z, Guo S, Wei R, et al. Centers for Disease Control and Prevention 2000 growth charts for the United States: improvements to the 1977 National Center for Health Statistics version. Pediatrics 2002;109(1):45-60.

[35] Leung SSF, Lau JTF, Tse LY, Oppenheimer SJ. Weight-for-age and weight-for height references for Hong Kong children from birth to 18 years. Journal of Paediatrics and Child Health 1996;32:103-9.

[36] Despres JP, Moorjani S, Lupien PJ, Tremblay A, Nadeau A, Bouchard C. Regional distribution of body fat, plasma lipoproteins, and cardiovascular disease. Arteriosclerosis 1990;10(4):497-511.

[37] Kahn HS, Valdez R. Metabolic risks identified by the combination of enlarged waist and elevated triacylglycerol concentration. Am J Clin Nutr 2003;78(5):928-34. 
[38] Kelishadi R, Gheiratmand R, Ardalan G, Adeli K, Mehdi Gouya M, Mohammad Razaghi E, et al. Association of anthropometric indices with cardiovascular disease risk factors among children and adolescents: CASPIAN Study. Int J Cardiol 2007;117(3):340-8. Epub 2006 Jul 21.

[39] Ng VW, Kong AP, Choi KC, Ozaki R, Wong GW, So WY, et al. BMI and waist circumference in predicting cardiovascular risk factor clustering in Chinese adolescents. Obesity (Silver Spring) 2007;15(2):494-503.

[40] Kannel WB, Cupples LA, Ramaswami R, Stokes J, 3rd, Kreger BE, Higgins M. Regional obesity and risk of cardiovascular disease; the Framingham Study. J Clin Epidemiol 1991;44(2):183-90.

[41] Björntorp P. Metabolic implications of body fat distribution. Diabetes Care 1991;14:1132-1143.

[42] Maffeis C, Pietrobelli A, Grezzani A, Provera S, Tato L. Waist circumference and cardiovascular risk factors in prepubertal children. Obes Res 2001;9(3):179-87.

[43] Seidell JC, Perusse L, Despres JP, Bouchard C. Waist and hip circumferences have independent and opposite effects on cardiovascular disease risk factors: the Quebec Family Study. Am J Clin Nutr 2001;74(3):315-21.

[44] Alberti KG, Zimmet P, Shaw J. The metabolic syndrome--a new worldwide definition. Lancet 2005;366(9491):1059-62.

[45] Moreno LA, Fleta J, Mur L, Rodriquez G, Sarria A, Bueno M. Waist circumference values in Spanish children--gender related differences. Eur J Clin Nutr 1999;53(6):429-33.

[46] McCarthy HD, Jarrett KV, Crawley HF. The development of waist circumference percentiles in British children aged 5.0-16.9 y. Eur J Clin Nutr 2001;55(10):902-7.

[47] Fredriks AM, van Buuren S, Fekkes M, Verloove-Vanhorick SP, Wit JM. Are age references for waist circumference, hip circumference and waist-hip ratio in Dutch children useful in clinical practice? Eur J Pediatr 2005;164(4):216-22. Epub 2005 Jan 21.

[48] Kelishadi R, Gouya MM, Ardalan G, Hosseini M, Motaghian M, Delavari A, et al. First reference curves of waist and hip circumferences in an Asian population of youths: CASPIAN study. J Trop Pediatr 2007;53(3):158-64. Epub 2007 Feb 17.

[49] Sung RY, So HK, Choi KC, Nelson EA, Li AM, Yin JA, et al. Waist circumference and waist-to-height ratio of Hong Kong Chinese children. BMC Public Health 2008;8:324.

[50] Zannolli R, Morgese G. Waist percentiles: a simple test for atherogenic disease? Acta Paediatr 1996;85(11):1368-9.

[51] Savva SC, Kourides Y, Tornaritis M, Epiphaniou-Savva M, Tafouna P, Kafatos A. Reference growth curves for cypriot children 6 to 17 years of age. Obes Res 2001;9(12):754-62.

[52] Katzmarzyk PT. Waist circumference percentiles for Canadian youth 11-18y of age. Eur J Clin Nutr 2004;58(7):1011-5.

[53] Fernandez JR, Redden DT, Pietrobelli A, Allison DB. Waist circumference percentiles in nationally representative samples of African-American, European-American, and Mexican-American children and adolescents. J Pediatr 2004;145(4):439-44. 
[54] Weili Y, He B, Yao H, Dai J, Cui J, Ge D, et al. Waist-to-height ratio is an accurate and easier index for evaluating obesity in children and adolescents. Obesity (Silver Spring) 2007;15(3):748-52.

[55] Jones KL. Role of obesity in complicating and confusing the diagnosis and treatment of diabetes in children. Pediatrics 2008;121(2):361-8.

[56] Kong AP, Chan JC. Atherosclerosis in young people with type 2 diabetes. International Diabetes Monitor 2010;22(5):223-224.

[57] American Diabetes Association. Standards of Medical Care in Diabetes-2010. Diabetes Care 2010;33 (Suppl):S11-61.

[58] Kong AP, Chan JC. Other Disorders with Type 1 Phenotype. Textbook of Diabetes 2010(4th Edition):9.14-9.21.

[59] Flint A, Arslanian S. Treatment of type 2 diabetes in youth. Diabetes 2011;34(Suppl 2):S177-83.

[60] Sarnblad S, Kroon M, Aman J. Metformin as additional therapy in adolescents with poorly controlled type 1 diabetes: randomised placebo-controlled trial with aspects on insulin sensitivity. Eur J Endocrinol 2003;149(4):323-9.

[61] Weigensberg MJ, Goran MI. Type 2 diabetes in children and adolescents. Lancet 2009;373(9677):1743-4.

[62] Rosenbloom AL, Silverstein JH, Amemiya S, Zeitler P, Klingensmith GJ. Type 2 diabetes in children and adolescents. Pediatr Diabetes 2009;10(Suppl 12):17-32.

[63] Muntner P, He J, Cutler JA, Wildman RP, Whelton PK. Trends in blood pressure among children and adolescents. JAMA 2004;291(17):2107-13.

[64] Leung LC, Sung RY, So HK, Wong SN, Lee KW, Lee KP, et al. Prevalence and risk factors for hypertension in Hong Kong Chinese adolescents: waist circumference predicts hypertension, exercise decreases risk. Arch Dis Child 2011;96(9):804-9.

[65] Raitakari OT, Porkka KV, Rasanen L, Ronnemaa T, Viikari JS. Clustering and six year cluster-tracking of serum total cholesterol, HDL-cholesterol and diastolic blood pressure in children and young adults. The Cardiovascular Risk in Young Finns Study. J Clin Epidemiol 1994;47(10):1085-93.

[66] Bao W, Threefoot SA, Srinivasan SR, Berenson GS. Essential hypertension predicted by tracking of elevated blood pressure from childhood to adulthood: the Bogalusa Heart Study. Am J Hypertens 1995;8(7):657-65.

[67] Tracy RE, Newman WP, 3rd, Wattigney WA, Srinivasan SR, Strong JP, Berenson GS. Histologic features of atherosclerosis and hypertension from autopsies of young individuals in a defined geographic population: the Bogalusa Heart Study. Atherosclerosis 1995;116(2):163-79.

[68] Homma S, Ishii T, Malcom GT, Zieske AW, Strong JP, Tsugane S, et al. Histopathological modifications of early atherosclerotic lesions by risk factors-findings in PDAY subjects. Atherosclerosis 2001;156(2):389-99.

[69] National High Blood Pressure Education Program Working Group on High Blood Pressure in Children and Adolescents. The fourth report on the diagnosis, evaluation, and treatment of high blood pressure in children and adolescents. Pediatrics 2004;114(2 Suppl 4th Report):555-76. 
[70] Sung RY, Choi KC, So HK, Nelson EA, Li AM, Kwok CW, et al. Oscillometrically measured blood pressure in Hong Kong Chinese children and associations with anthropometric parameters. J Hypertens 2008;26(4):678-84.

[71] Falkner B, Gidding SS, Portman R, Rosner B. Blood pressure variability and classification of prehypertension and hypertension in adolescence. Pediatrics 2008;122(2):238-42.

[72] Stergiou GS, Rarra VC, Yiannes NG. Changing relationship between home and office blood pressure with increasing age in children: the Arsakeion School study. Am J Hypertens 2008;21(1):41-6.

[73] Urbina E, Alpert B, Flynn J, Hayman L, Harshfield GA, Jacobson M, et al. Ambulatory blood pressure monitoring in children and adolescents: recommendations for standard assessment: a scientific statement from the American Heart Association Atherosclerosis, Hypertension, and Obesity in Youth Committee of the council on cardiovascular disease in the young and the council for high blood pressure research. Hypertension 2008;52(3):433-51.

[74] Nicklas TA, von Duvillard SP, Berenson GS. Tracking of serum lipids and lipoproteins from childhood to dyslipidemia in adults: the Bogalusa Heart Study. Int J Sports Med 2002;23(Suppl 1):S39-43.

[75] de Ferranti SD, Gauvreau K, Ludwig DS, Neufeld EJ, Newburger JW, Rifai N. Prevalence of the metabolic syndrome in American adolescents: findings from the Third National Health and Nutrition Examination Survey. Circulation 2004;110(16):2494-7.

[76] Cook S, Weitzman M, Auinger P, Nguyen M, Dietz W. Prevalence of a metabolic syndrome phenotype in adolescents. Findings from the Third National Health and Nutrition Examination Survey, 1988-1994. Arch Pediatr Adolesc Med 2003;157:821827.

[77] Ford ES, Ajani UA, Mokdad AH. The metabolic syndrome and concentrations of Creactive protein among U.S. youth. Diabetes Care 2005;28(4):878-81.

[78] Kong AP, Choi KC, Cockram CS, Ho CS, Chan MH, Ozaki R, et al. Independent associations of alanine aminotransferase (ALT) levels with cardiovascular risk factor clustering in Chinese adolescents. J Hepatol 2008;49(1):115-122.

[79] Cruz ML, Weigensberg MJ, Huang TT, Ball G, Shaibi GQ, Goran MI. The metabolic syndrome in overweight Hispanic youth and the role of insulin sensitivity. J Clin Endocrinol Metab 2004;89(1):108-13.

[80] Weiss R, Dziura J, Burgert TS, Tamborlane WV, Taksali SE, Yeckel CW, et al. Obesity and the metabolic syndrome in children and adolescents. $\mathrm{N}$ Engl J Med 2004;350(23):2362-74.

[81] Grundy SM. Metabolic syndrome scientific statement by the American Heart Association and the National Heart, Lung, and Blood Institute. Arterioscler Thromb Vasc Biol 2005;25(11):2243-4.

[82] Goodman E, Daniels SR, Meigs JB, Dolan LM. Instability in the diagnosis of metabolic syndrome in adolescents. Circulation 2007;115(17):2316-22.

[83] Expert Panel on Detection Evaluation and Treatment of high blood cholesterol in adults. Executive summary of the Third Report of the National Cholesterol Education Program Expert Panel on Detection, Evaluation and Treatment of 
high blood cholesterol in adults (Adult Treatment Panel III). JAMA 2001;285:2486-97.

[84] McCrindle BW, Urbina EM, Dennison BA, Jacobson MS, Steinberger J, Rocchini AP, et al. Drug therapy of high-risk lipid abnormalities in children and adolescents: a scientific statement from the American Heart Association Atherosclerosis, Hypertension, and Obesity in Youth Committee, Council of Cardiovascular Disease in the Young, with the Council on Cardiovascular Nursing. Circulation 2007;115(14):1948-67.

[85] McNeal C, Wilson DP. Metabolic syndrome and dyslipidemia in youth. J Clin Lipidol 2008;2(3):147-55.

[86] Iglowstein I, Jenni OG, Molinari L, Largo RH. Sleep duration from infancy to adolescence: reference values and generational trends. Pediatrics 2003;111(2):302-7.

[87] National Sleep Foundation. National Sleep Foundation 2005 Omnibus "Sleep in America" Poll. 2005:Available at: http://www/sleepfoundation.org.

[88] Broman JE, Lundh LG, Hetta J. Insufficient sleep in the general population. Neurophysiol Clin 1996;26(1):30-9.

[89] Van Cauter E, Knutson K. Sleep and the epidemic of obesity in children and adults. Eur J Endocrinol 2008:[Epub ahead of print].

[90] Van Cauter E, Knutson K. Sleep and the epidemic of obesity in children and adults. Eur J Endocrinol 2008;159(Suppl):S59-66.

[91] Van Cauter E, Holmback U, Knutson K, Leproult R, Miller A, Nedeltcheva A, et al. Impact of sleep and sleep loss on neuroendocrine and metabolic function. Horm Res 2007;67(Suppl 1):2-9.

[92] Taheri S. The link between short sleep duration and obesity: we should recommend more sleep to prevent obesity. Arch Dis Child 2006;91(11):881-4.

[93] Reilly JJ, Armstrong J, Dorosty AR, Emmett PM, Ness A, Rogers I, et al. Early life risk factors for obesity in childhood: cohort study. BMJ 2005;330(7504):1357.

[94] Sekine M, Yamagami T, Hamanishi S, Handa K, Saito T, Nanri S, et al. Parental obesity, lifestyle factors and obesity in preschool children: results of the Toyama Birth Cohort study. J Epidemiol 2002;12(1):33-9.

[95] Shigeta H, Shigeta M, Nakazawa A, Nakamura N, Yoshikawa T. Lifestyle, obesity, and insulin resistance. Diabetes Care 2001;24(3):608.

[96] Taheri S, Lin L, Austin D, Young T, Mignot E. Short sleep duration is associated with reduced leptin, elevated ghrelin, and increased body mass index. PLoS Med 2004;1(3):e62.

[97] Vorona RD, Winn MP, Babineau TW, Eng BP, Feldman HR, Ware JC. Overweight and obese patients in a primary care population report less sleep than patients with a normal body mass index. Arch Intern Med 2005;165(1):25-30.

[98] Chaput JP, Brunet M, Tremblay A. Relationship between short sleeping hours and childhood overweight/obesity: results from the 'Quebec en Forme' Project. Int J Obes (Lond) 2006;30(7):1080-5.

[99] Gupta NK, Mueller WH, Chan W, Meininger JC. Is obesity associated with poor sleep quality in adolescents? Am J Hum Biol 2002;14(6):762-8. 
[100] Locard E, Mamelle N, Billette A, Miginiac M, Munoz F, Rey S. Risk factors of obesity in a five year old population. Parental versus environmental factors. Int J Obes Relat Metab Disord 1992;16(10):721-9.

[101] von Kries R, Toschke AM, Wurmser H, Sauerwald T, Koletzko B. Reduced risk for overweight and obesity in 5- and 6-y-old children by duration of sleep--a crosssectional study. Int J Obes Relat Metab Disord 2002;26(5):710-6.

[102] Knutson KL. Sex differences in the association between sleep and body mass index in adolescents. J Pediatr 2005;147(6):830-4.

[103] Agras WS, Hammer LD, McNicholas F, Kraemer HC. Risk factors for childhood overweight: a prospective study from birth to 9.5 years. J Pediatr 2004;145(1):20-5.

[104] Chen MY, Wang EK, Jeng YJ. Adequate sleep among adolescents is positively associated with health status and health-related behaviors. BMC Public Health 2006;6:59.

[105] Leproult R, Copinschi G, Buxton O, Van Cauter E. Sleep loss results in an elevation of cortisol levels the next evening. Sleep 1997;20(10):865-70.

[106] Spiegel K, Leproult R, Van Cauter E. Impact of sleep debt on metabolic and endocrine function. Lancet 1999;354(9188):1435-9.

[107] Spiegel K, Tasali E, Penev P, Van Cauter E. Brief communication: Sleep curtailment in healthy young men is associated with decreased leptin levels, elevated ghrelin levels, and increased hunger and appetite. Ann Intern Med 2004;141(11):846-50.

[108] Spiegel K, Leproult R, L'Hermite-Baleriaux M, Copinschi G, Penev PD, Van Cauter E. Leptin levels are dependent on sleep duration: relationships with sympathovagal balance, carbohydrate regulation, cortisol, and thyrotropin. J Clin Endocrinol Metab 2004;89(11):5762-71.

[109] Kudo T, Horikawa K, Shibata S. Circadian rhythms in the CNS and peripheral clock disorders: the circadian clock and hyperlipidemia. J Pharmacol Sci 2007;103(2):13943.

[110] Kaneita Y, Uchiyama M, Yoshiike N, Ohida T. Associations of usual sleep duration with serum lipid and lipoprotein levels. Sleep 2008;31(5):645-52.

[111] Gangwisch JE, Malaspina D, Babiss LA, Opler MG, Posner K, Shen S, et al. Short sleep duration as a risk factor for hypercholesterolemia: analyses of the National Longitudinal Study of Adolescent Health. Sleep 2010;33(7):956-61.

[112] Kong AP, Wing YK, Choi KC, Li AM, Ko GT, Ma RC, et al. Associations of sleep duration with obesity and serum lipid profile in children and adolescents. Sleep Medicine 2011;12(7):659-65.

[113] Kelishadi R. Inflammation-induced atherosclerosis as a target for prevention of cardiovascular diseases from early life. Open Cardiovasc Med J 2010;4:24-9.

[114] Schmidt MI, Duncan BB, Sharrett AR, Lindberg G, Savage PJ, Offenbacher S, et al. Markers of inflammation and prediction of diabetes mellitus in adults (Atherosclerosis risks in communities study): a cohort study. Lancet 1999;353:164952. 
[115] Tong PCY, Lee KF, So WY, Ng MCY, Chan WB, Lo MKW, et al. Association of white blood cell counts with macrovascular and microvascular complications in Chinese patients with type 2 diabetes. Diabetes Care 2004;27:216-222.

[116] Misra A. C-reactive protein in young individuals: problems and implications for Asian Indians. Nutrition 2004;20(5):478-81.

[117] Eckel RH, Grundy SM, Zimmet PZ. The metabolic syndrome. Lancet 2005;365(9468):1415-28.

[118] Kelishadi R, Hashemipour M, Ashtijou P, Mirmoghtadaee P, Poursafa P, Khavarian N, et al. Association of cell blood counts and cardiometabolic risk factors among young obese children. Saudi Med J 2010;31(4):406-12.

[119] Huang M, Choi SJ, Kim DW, Kim NY, Park CH, Yu SD, et al. Risk assessment of lowlevel cadmium and arsenic on the kidney. J Toxicol Environ Health A 2009;72(2122):1493-8.

[120] Houston MC. The role of mercury and cadmium heavy metals in vascular disease, hypertension, coronary heart disease, and myocardial infarction. Altern Ther Health Med 2007;13(2):S128-33.

[121] Hong F, Jin T, Zhang A. Risk assessment on renal dysfunction caused by co-exposure to arsenic and cadmium using benchmark dose calculation in a Chinese population. Biometals 2004;17(5):573-80.

[122] Navas-Acien A, Silbergeld EK, Sharrett R, Calderon-Aranda E, Selvin E, Guallar E. Metals in urine and peripheral arterial disease. Environ Health Perspect 2005;113(2):164-9.

[123] Poursafa P, Kelishadi R, Amini A, Amini A, Amin MM, Lahijanzadeh M, et al. Association of air pollution and hematologic parameters in children and adolescents. J Pediatr (Rio J) 2011;87(4):350-6.

[124] Poursafa P, Kelishadi R. Air pollution, platelet activation and atherosclerosis. Inflamm Allergy Drug Targets 2010;9(5):387-92.

[125] Alissa EM, Ferns GA. Heavy metal poisoning and cardiovascular disease. J Toxicol 2011;2011:870125.

[126] Kristensen PL, Moller NC, Korsholm L, Wedderkopp N, Andersen LB, Froberg K. Tracking of objectively measured physical activity from childhood to adolescence: the European youth heart study. Scand J Med Sci Sports 2008;18(2):171-8.

[127] Baker JL, Olsen LW, Sorensen TI. Childhood body-mass index and the risk of coronary heart disease in adulthood. N Engl J Med 2007;357(23):2329-37.

[128] Ludwig DS. The glycemic index: physiological mechanisms relating to obesity, diabetes, and cardiovascular disease. JAMA 2002;287(18):2414-23.

[129] Brand-Miller J, McMillan-Price J, Steinbeck K, Caterson I. Carbohydrates--the good, the bad and the whole grain. Asia Pac J Clin Nutr 2008;17(Suppl 1):16-9.

[130] Krishnan S, Rosenberg L, Singer M, Hu FB, Djousse L, Cupples LA, et al. Glycemic index, glycemic load, and cereal fiber intake and risk of type 2 diabetes in US black women. Arch Intern Med 2007;167(21):2304-9.

[131] Villegas R, Liu S, Gao YT, Yang G, Li H, Zheng W, et al. Prospective study of dietary carbohydrates, glycemic index, glycemic load, and incidence of type 2 diabetes mellitus in middle-aged Chinese women. Arch Intern Med 2007;167(21):2310-6. 
[132] Obesity: preventing and managing the global epidemic. Report of a WHO consultation. World Health Organ Tech Rep Ser;2000;894:i-xii.

[133] Kong AP, Chan RS, Nelson EA, Chan JC. Role of low-glycemic index diet in management of childhood obesity. Obes Rev 2011;12(7):492-8.

[134] Kong AP, Choi KC, Li AM, Hui SS, Chan MH, Wing YK, et al. Association between physical activity and cardiovascular risk in Chinese youth independent of age and pubertal stage. BMC Public Health 2010;10:303.

[135] Esparza J, Fox C, Harper IT, Bennett PH, Schulz LO, Valencia ME, et al. Daily energy expenditure in Mexican and USA Pima indians: low physical activity as a possible cause of obesity. Int J Obes Relat Metab Disord 2000;24(1):55-9.

[136] Bell AC, Ge K, Popkin BM. Weight gain and its predictors in Chinese adults. Int J Obes Relat Metab Disord 2001;25(7):1079-86.

[137] Erlichman J, Kerbey AL, James WP. Physical activity and its impact on health outcomes. Paper 1: The impact of physical activity on cardiovascular disease and all-cause mortality: an historical perspective. Obes Rev 2002;3(4):257-71.

[138] Inoue M, Iso H, Yamamoto S, Kurahashi N, Iwasaki M, Sasazuki S, et al. Daily total physical activity level and premature death in men and women: results from a large-scale population-based cohort study in Japan (JPHC study). Ann Epidemiol 2008;18(7):522-30.

[139] Ballor DL, Keesey RE. A meta-analysis of the factors affecting exercise-induced changes in body mass, fat mass and fat-free mass in males and females. Int J Obes 1991;15(11):717-26.

[140] Baba R, Koketsu M, Nagashima M, Inasaka H. Role of exercise in the prevention of obesity and hemodynamic abnormalities in adolescents. Pediatr Int 2009;51(3):35963.

[141] Knowler WC, Barrett-Connor E, Fowler SE, Hamman RF, Lachin JM, Walker EA, et al. Reduction in the incidence of type 2 diabetes with lifestyle intervention or metformin. N Engl J Med 2002;346:393-403.

[142] Khan NA, Hemmelgarn B, Herman RJ, Bell CM, Mahon JL, Leiter LA, et al. The 2009 Canadian Hypertension Education Program recommendations for the management of hypertension: Part 2--therapy. Can J Cardiol 2009;25(5):287-98.

[143] Sung RY, Yu CW, Chang SK, Mo SW, Woo KS, Lam CW. Effects of dietary intervention and strength training on blood lipid level in obese children. Arch Dis Child 2002;86(6):407-10.

[144] World Health Organization. Global strategy on diet, physical activity and health. Geneva 2004; World Health Organization:2004.

[145] Strong WB, Malina RM, Blimkie CJ, Daniels SR, Dishman RK, Gutin B, et al. Evidence based physical activity for school-age youth. J Pediatr 2005;146(6):732-7.

[146] American College of Sports Medicine. Physical fitness in children and youth. Med Sci Sports Exerc 1998;20:422-23.

[147] World Health Organization 2007. Steps to Health: A European Framework to Promote Physical Activity for Health.

http:/ / www.euro.who.int/Document/E90191.pdf. 
[148] Andersen LB, Harro M, Sardinha LB, Froberg K, Ekelund U, Brage S, et al. Physical activity and clustered cardiovascular risk in children: a cross-sectional study (The European Youth Heart Study). Lancet 2006;368(9532):299-304. 


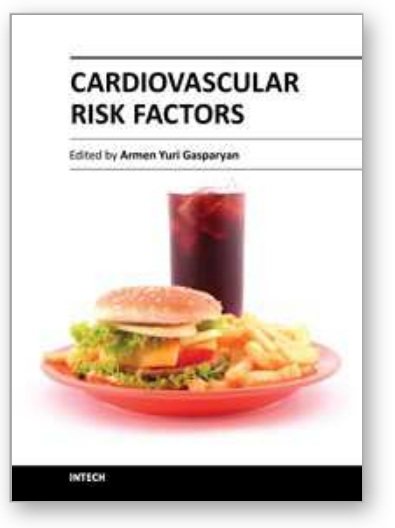

\author{
Cardiovascular Risk Factors \\ Edited by Prof. Armen Gasparyan
}

ISBN 978-953-51-0240-3

Hard cover, 498 pages

Publisher InTech

Published online 14, March, 2012

Published in print edition March, 2012

Cardiovascular risk factors contribute to the development of cardiovascular disease from early life. It is thus crucial to implement preventive strategies addressing the burden of cardiovascular disease as early as possible. A multidisciplinary approach to the risk estimation and prevention of vascular events should be adopted at each level of health care, starting from the setting of perinatology. Recent decades have been marked with major advances in this field, with the emergence of a variety of new inflammatory and immunemediated markers of heightened cardiovascular risk in particular. The current book reflects some of the emerging concepts in cardiovascular pathophysiology and the shifting paradigm of cardiovascular risk estimation. It comprehensively covers primary and secondary preventive measures targeted at different age and gender groups. Attention is paid to inflammatory and metabolic markers of vascular damage and to the assessment of vascular function by noninvasive standardized ultrasound techniques. This is a must-read book for all health professionals and researchers tackling the issue of cardiovascular burden at individual and community level. It can also serve as a didactic source for postgraduate medical students.

\title{
How to reference
}

In order to correctly reference this scholarly work, feel free to copy and paste the following:

Alice P.S. Kong and Kai Chow Choi (2012). Novel and Traditional Cardiovascular Risk Factors in Adolescents, Cardiovascular Risk Factors, Prof. Armen Gasparyan (Ed.), ISBN: 978-953-51-0240-3, InTech, Available from: http://www.intechopen.com/books/cardiovascular-risk-factors/-cardiovascular-risk-factors-in-adolescents-

\section{INTECH}

open science | open minds

\section{InTech Europe}

University Campus STeP Ri

Slavka Krautzeka 83/A

51000 Rijeka, Croatia

Phone: +385 (51) 770447

Fax: +385 (51) 686166

www.intechopen.com

\section{InTech China}

Unit 405, Office Block, Hotel Equatorial Shanghai

No.65, Yan An Road (West), Shanghai, 200040, China

中国上海市延安西路65号上海国际贵都大饭店办公楼405单元

Phone: +86-21-62489820

Fax: $+86-21-62489821$ 
(C) 2012 The Author(s). Licensee IntechOpen. This is an open access article distributed under the terms of the Creative Commons Attribution 3.0 License, which permits unrestricted use, distribution, and reproduction in any medium, provided the original work is properly cited. 